\title{
Phytochemical, Pharmacognostic and Pharmacological Studies on Zingiber Officinale
}

Mohammad Kamil*, F Ahmad, M T Abdallah

ZCHRTM, DOH, A.D.UAE.

*Corresponding Author: Mohammad Kamil, ZCHRTM, DOH, A.D, UAE.

Received Date: 18 October 2021 | Accepted Date: 26 November 2021 | Published Date: 06 January 2021

Citation: M Kamil, F Ahmad, M T Abdallah (2022). Phytochemical, Pharmacognostic and Pharmacological Studies on Zingiber Officinale. Journal of Clinical and Laboratory Research. 5(1): DOI:10.31579/2768-0487/041

Copyright: (c) 2022 Mohammad Kamil, This is an open-access article distributed under the terms of the Creative Commons Attribution License, which permits unrestricted use, distribution, and reproduction in any medium, provided the original author and source are credited.

\begin{abstract}
Rhizomes of Zingiber officinale Roscoe. belonging to the family Zingiberaceae is used for bronchitis, as a carminative, for treating cough, cataracts and as a stimulant. The rhizome is cooked with salt and water and used as an expectorant. Extract of the juice of rhizome is used aseye-drops. In Yemen, it is mixed with other plants used for constipation, as a purgative, against colds, catarrh and acidity of the stomach. Root ginger is widely used for culinary purposes and asa spice. The rhizomes (imported from India) are used with cinnamon and cloves and made into atea for treating colds and as a general tonic. The drink is also used as an aphrodisiac (Gazanfar, 1994).

Ginger is useful in piles, rheumatism, headache, lumbago, pains, bleeding, chest congestion, cholera, cold, diarrhea, dropsy, nausea, stomachache, gastrointestinal disorders, vomiting, and diarrhea. The fresh juice of ginger acts as a strong diuretic. The juice of the leaves is effective against helminthiasis and marasmus and related conditions of diarrhea and dysentery (Monograph of Unani Medicine, 2003).
\end{abstract}

Keywords: phytochemical; pharmacognostic ;pharmacological; zingiber officinale

\section{Introduction}

Ginger is extremely valuable in dyspepsia, flatulence, colic, vomiting, spasms and other painful affections of the stomach, and the bowls unattended by fevers for cold, cough, asthma, dyspepsiaand indigestion. Aromatic, carminative, stimulant to gastrointestinal tract, and stomachic; also digestive. Externally a local stimulant and rubefacient (Kapoor, 2001).

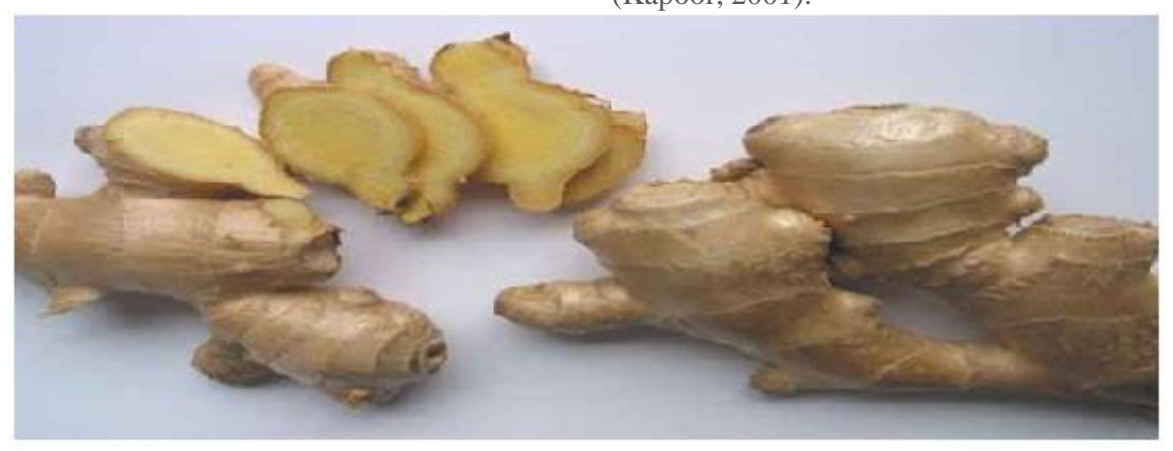

It is a pale yellowish branched rhizome and it is laterally compressed with longitudinally striated surfaces giving a coarse feeling when touched between fingers. When a branch is cut, it shows fibrous structures.

A transverse section of a branch of the rhizome is oblong in outline. As the sample is composed of an unpeeled rhizome, the outermost layers are composed of brown cork cells underlain by layers of collapsed parenchyma cells. which are brownish-yellow in color. These are surrounding the cortex, which occupies a large zone, and it consists of rounded and polygonal parenchyma cells and they are almost light yellow in color. Many of the cortical parenchyma cells contain oblong or pear-shaped starch granules. Scattered between these cells are many yellow-colored rounded or oval cells that contain 
droplets of yellow oil. The cortex is underlain by a clear endoclermis layer with collapsed cells. The numerous vascular bundles, which are light gray in color, are scattered in both cortex and the yellow-colored stele. The xylem vessels are annularly, spirally, or reticulately thickened. The vascular bundles are almost surrounded by a group of fibers, which are long and they have thick walls that are pitted and one side of the walls is dentate. These fibers also have thin transverse septa,
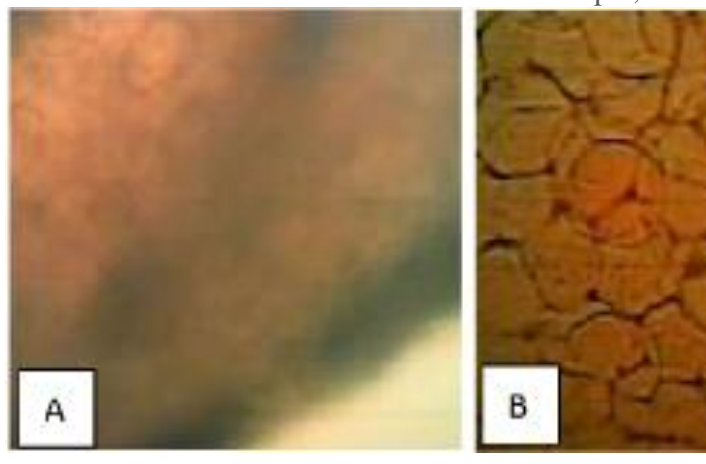

\section{Chemical Constituents:}

The rhizome contains $1-4 \%$ essential oil and an oleoresin. The chief constituents of essential oil are sesquiterpenes (1\%-3\%) which include ()-zingiberene, $\quad(+)$-ar-curcumene, $\quad(-) \quad \beta$-sesquiphellandrene, $\quad \beta$ bisabolene,citral and citronellyl acetate (Wagner,H. ,1996). Heptane, octane, isovaleraldehyde, nonanol, ethyl pinene, camphene, $\beta$-pinene, sabinene, myrecene, limonene, $\beta$-phellandrene and 1,8-cineole, sequithujene, cis- sesquisabinene hydrate and zingiberenol (2-methyl6(trans-4'-methyl-4- hydroxycylohex-2-enyl)-hept-2-ene), car-3-ene, terpineol, nerol, neral, geranial, geraniol and geranyl acetate, $\alpha$ farnesene, $\beta$-farnesene, linalool, , gingerol, shogaol, dihydrogingerol, hexahydrocurcumin are also reported in the essential oil of rhizomes. Monoterpene aldehydes and alcohols are also present. Gingerols and shogaols (WHO, 1999).

Gingerdione: 1-dehydrogingerdione (Reena, 2000). Gingediol, methylgingediol and their diacetates. (6)-dehydroginerdione,(10)dehydrogingerdione,(6)-gingerdione and (10)-gingerdione and (6)gingerol from roots. Gingerdiones, hexahydrocurcumin and desmethylhexahydrocurcumin. Gingerols I, II and II from rhizomes. Asparticacid, threonine, serine, glycine, cysteine, valine, isoleucine, leucine and arginine from aerial parts and tuber.

(6)-shogaol,(6)-dehydrogingerdione,(8)-and (10)-gingerols are active constituents. Zingiberene, $\alpha$-curcumene, $\alpha$-copaene, undecan-2-one, neral and geranial from root essential oil. Zerumbone, zerumbodienone, humulene epoxide I and humulene epoxide II from roots. Galanolactone and (E) $8 \square, 17$-epoxylabd-12-en-15,16-dial along with (6)- shogaol,(6)- which are observed at intervals. The central zone is occupied by the pith, which consists of polygonal or rounded cells among which are scattered rounded or oval cells that contain droplets of a yellowish volatile oil.

\section{Parts Studied: Rhizome}

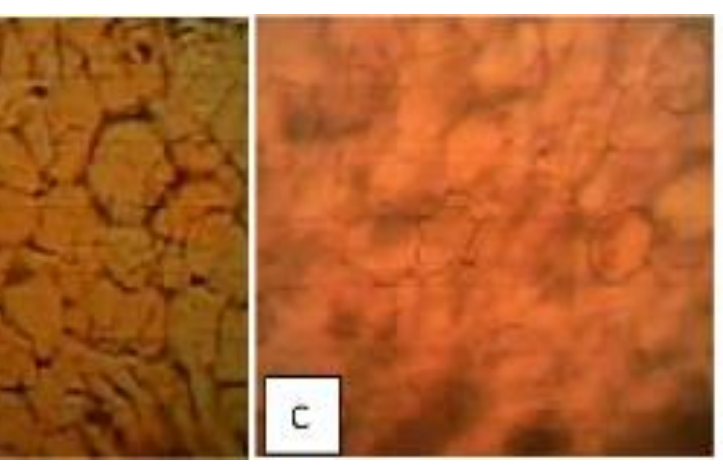

,(8)- and (10)-gingerols from roots. Diarylheptenones: gingerenone A, B, and C and isogingerenone B from rhizomes (Rastogi, 1991, 1993, 1995, 1998).

The following chemical studies have been carried out (Quality Control Methods, 1998; Evans, 1996) on the rhizome of Zingiber officinale (ZCHRTM unpublished work):

\section{Physicochemical Constants (\%)}

Loss of weight in drying at $105 \mathrm{oC}: 10.90$ Absolute alcohol solubility : 4.00 Water solubility $: 16.00$

\section{Successive Extractives (\%)}

Petroleum ether $\left(60-80{ }^{\circ} \mathrm{C}\right)$

Chloroform

Absolute alcohol

Ash Values (\%)
Total ash

Water soluble ash ash $(10 \% \mathrm{HCl})$

pH Values (aqueous solution)

$\mathrm{pH}$ of $1 \%$ solution

$\mathrm{pH}$ of $10 \%$ solution

\section{Elemental Analyses:}

\begin{tabular}{|c|c|c|c|c|c|}
\hline \multicolumn{6}{|c|}{ Ash values ( British Herbal Pharmacopeia- Reference) } \\
\hline \multicolumn{6}{|c|}{ Assay and identification of element (AOAC International- Reference) } \\
\hline \multirow{2}{*}{$\begin{array}{l}\text { Apparatus } \\
\text { Element }\end{array}$} & \multicolumn{5}{|c|}{ (AA-6800 Shimadzu-Flame method) } \\
\hline & $\begin{array}{l}\text { Std. conc. } \mu \mathrm{g} / \mathrm{ml} \\
(\mathrm{ppm})\end{array}$ & $\begin{array}{l}\text { Sample } \\
\text { conc. } \\
\mathrm{mg} / \mathrm{ml}\end{array}$ & $\begin{array}{l}\text { Sample } \\
\text { absorbance }\end{array}$ & $\begin{array}{l}\text { Actual conc. } \\
\mathrm{mg} / \mathrm{ml}\end{array}$ & Actual conc. $(\%)$ \\
\hline $\mathrm{Cr}$ & $1,2,4$ & 9.995 & 0.0000 & $<0.0001$ & $<0.001$ \\
\hline $\mathrm{Zn}$ & $0.25,0.5,1$ & 9.995 & 0.1388 & 0.04169 & 0.004169 \\
\hline $\mathrm{Cu}$ & $1,2,4$ & 9.995 & 0.006 & 0.00722 & 0.00072 \\
\hline
\end{tabular}




\begin{tabular}{|l|l|l|l|l|l|}
\hline $\mathrm{Fe}$ & $1,2,4$ & 0.9086 & 0.0274 & 0.05051 & 0.005051 \\
\hline $\mathrm{K}$ & $1,2,4$ & 0.9086 & 1.4268 & 10.88296 & 1.088296 \\
\hline $\mathrm{Pb}$ & $1,2,4$ & 9.995 & 0.0000 & $<0.0001$ & $<0.00001$ \\
\hline $\mathrm{Cd}$ & $0.125,0.25,0.5$ & 9.995 & 0.0000 & $<0.00001$ & $<0.000001$ \\
\hline $\mathrm{Ca}$ & $5,10,20$ & 0.826 & 0.0193 & 5.529864 & 0.552986 \\
\hline $\mathrm{Mg}$ & $0.25,0.5,1$ & 0.0826 & 0.2825 & 2.90884 & 0.290884 \\
\hline $\mathrm{Na}$ & $1,2,4$ & 0.9086 & 0.09992 & 2.2693 & 0.22693 \\
\hline
\end{tabular}

$1 \mathrm{ppm}$ conc. $=1 \mu \mathrm{g} / \mathrm{ml}$; Actual conc. $(\%)=$ Actual conc. $(\mathrm{ppm}) \times 0.0001[1 \mathrm{ppm}=0.0001 \%]$

\section{UV Spectral Studies:}

\begin{tabular}{|c|c|c|c|c|}
\hline \multicolumn{5}{|c|}{ Ultraviolet Spectrum (USP reference) } \\
\hline Apparatus & \multicolumn{4}{|c|}{ Beckman DU 520 general purpose UV/VIS spectrophotometer. } \\
\hline $\begin{array}{l}\text { Sample conc. } \\
\text { (mg / ml) }\end{array}$ & Solvent & $\begin{array}{ll}\lambda & \max \\
(\mathrm{nm}) & \end{array}$ & $\begin{array}{l}\lambda \min \\
(\mathrm{nm})\end{array}$ & $\begin{array}{l}\operatorname{Abs.}(\lambda \max =\lambda \\
\min )\end{array}$ \\
\hline 0.60636 & $\begin{array}{l}\text { Intestinal Fluid simulated } \\
\text { without pancreatic } \\
\mathrm{pH}=7.5 \pm 0.1\end{array}$ & $\begin{array}{l}205.5 \\
277.5\end{array}$ & 260.5 & $\begin{array}{l}2.007 \\
0.323-0.296\end{array}$ \\
\hline 0.83666 & $\begin{array}{l}\text { Gastric Fluid simulated } \\
\text { without pepsin } \mathrm{pH}=1.2 \pm 0.1\end{array}$ & $\begin{array}{l}204 \\
280.5\end{array}$ & 257.5 & $\begin{array}{l}1.857 \\
0.324-0.276\end{array}$ \\
\hline
\end{tabular}

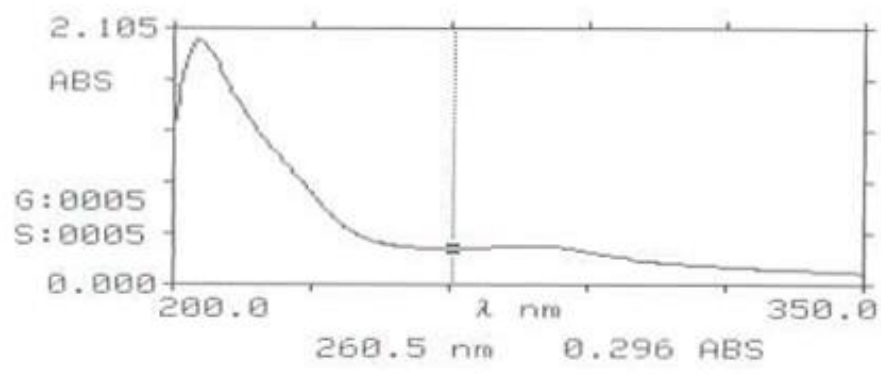

Intestinal Fluid simulated without pancreatic $\mathrm{pH}=7.5 \pm 0.1$

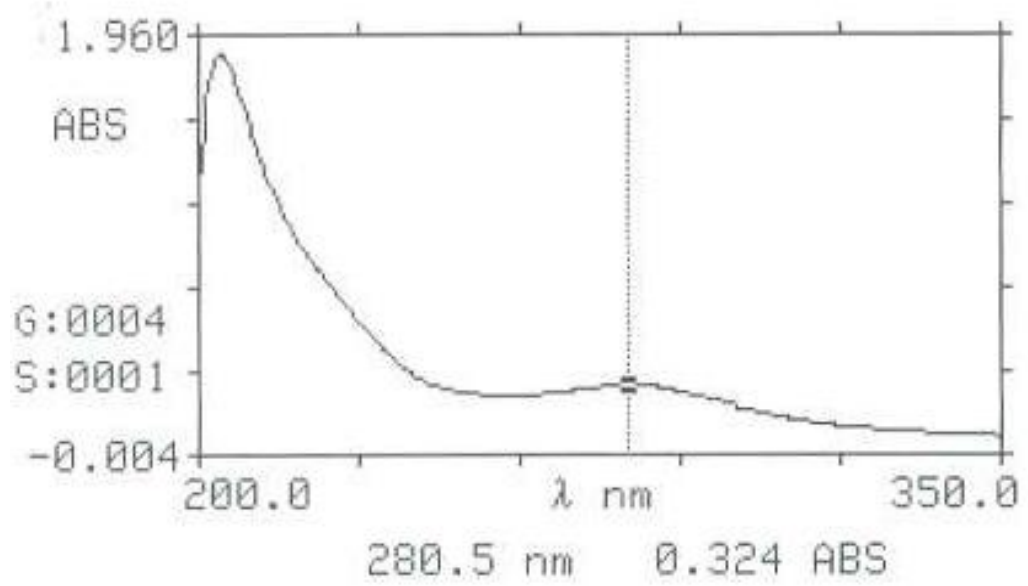

Gastric Fluid simulated without pepsin $\mathrm{pH}=1.2 \pm 0.1$

Thin layer chromatography (TLC): (Wagner, 1996) 

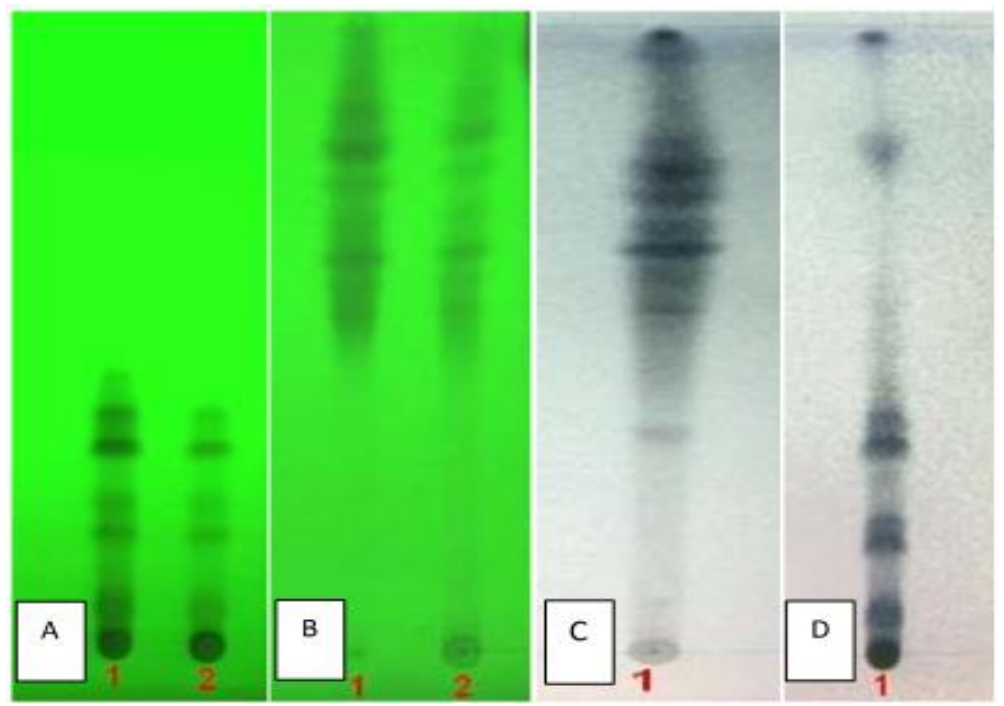

TLC fingerprint of Petroleum ether $-60-80{ }^{\circ} \mathrm{C}$ extract (track 1) and MeOH extract (track 2)Mobile phase Fig. A \& D: Toluene, ethyl acetate (93:7) B \& C: Toluene, ethyl formate, formic acid (5:4:1)Detection A \& B: UV

254nm Derivatization C \& D: Vanillin-Sulphuric acid under normal light

\section{Pharmacological \& Toxicological Studies:}

Literature and reported information about the plant: General pharmacological studies were performed on ginger and shogaol, which are the pungent constituents of ginger (Zingiber officinale Roscoe). Intravenous (IV) administration of gingerol at $(1.75-3.5 \mathrm{mg} / \mathrm{kg}$ ) or shogaol (at $1.75-3.5 \mathrm{mg} / \mathrm{kg}$ ) and oral administration of them (at 70-140 $\mathrm{mg} / \mathrm{kg}$ ) produced an inhibition of spontaneous motor activity, antipyretic and analgesic effects, prolonged hexobarbital-induced sleeping time. These effects of shogaol were mostly more intensive than that of gingerol.

Shogaol showed an intense antitussive effect in comparison with dihydrocodeine phosphate. In the electro-encephalogram of cortex, the low amplitude fast wave pattern was observed for $5 \mathrm{~min}$ after IV administration of shogaol, and then changed to the drowsy pattern, which was restored after $60 \mathrm{~min}$. In the gastro-intestinal system, shogaol intensively inhibited the traverse of charcoal meal through the intestine in contrast with gingerol after IV administration of $3.5 \mathrm{mg} / \mathrm{kg}$, but shogaol facilitated such an intestinal function after oral administration of 35 $\mathrm{mg} / \mathrm{kg}$. Both shogaol and gingerol suppressed gastric contraction in situ, and the suppression by the former was more intensive than that by the latter. In the cardiovascular system, both shogaol and gingerol produced depressor response at lower doses on the blood pressure. At high doses, both drugs produced three phase pattern (Suekawa, 1984). Ethanolic decoction of Zingiber officinale $(200 \mathrm{mg} / \mathrm{kg})$ fed orally for 20 days produced significant antihyperglycaemic effect $(\mathrm{P}=<0.01)$ in diabetic rats (Bhandari, 2005). The cytoprotective and gastric anti-ulcer studies of ginger that have been carried out in albino rats indicates the cytoprotective and anti-ulcerogenic effects of the ginger (Al-Yahiya, 1989).

In humans, ginger is thought to act directly on the gastrointestinal system to reduce nausea (Holtmann, 1989). Ginger has been shown to reduce the symptoms of motion sickness associated with travel by boat and, to a lesser extent (Grontved, 1988), (Ribenfeld, 1999), (Careddu, 1999). Two double-blind clinical trials have found that ginger may reduce nausea due to anesthesia following surgery (Bone, 1990); (Phillips, 1993). However, one trial could not confirm this benefit (Arfeen, 1995). A preliminary trial has suggested ginger may be helpful for preventing chemotherapyinduced nausea (Meyer, 1995). While ginger is a popular remedy for nausea of pregnancy, it has only been clinically studied for very severe nausea and vomiting known as hyperemesis gravidarum (Langner, 1998). Ginger can be life threatening. Ginger contains some compounds that cause chromosomal mutation in the test tube. However, the available clinical research, combined with the fact that ginger is widely used in the diet of certain cultures, suggests that prudent use of ginger for morning sickness is safe in amounts up to 1 gram per day.

Ginger is considered a tonic for the digestive tract, stimulating digestion and toning the intestinal muscles (Bradley, 1992). Ginger may protect the stomach from the damaging effect of alcohol and non-steroidal antiinflammatory drugs (NSAIDs, such as ibuprofen) and may help prevent ulcers (Al-Yahya,1989).

Ginger also supports cardiovascular health. Ginger may make blood platelets less sticky and less likely to aggregate (Bordia, 1997), (Verma, 1993). However, not all human research has confirmed this (Lumb, 1994), (Janssen, 1996).

The efficacy of ginger for the prevention of postoperative nausea and vomiting was studied in a double-blind, randomized, controlled trial in 108 ASA 1 or 2 patients undergoing gynecological laparoscopic surgery under general anesthesia. These studies concluded that ginger BP in doses of 0.5 or 1.0 gram is ineffective in reducing the incidence of postoperative nausea and vomiting (Arfeen, 1995).

The effectiveness of ginger (Zingiber officinale) as an antiemetic agent was compared with

placebo and metoclopramide in 60 women who had major gynecological surgery in a double-blind, randomized study. The administration of antiemetic after operation was significantly greater in the placebo group compared to the other two groups $(\mathrm{p}=<0.05)$ (Bone, 1990).

In a placebo-controlled study, the effect of ginger and fenugreek was examined on blood lipids, blood sugar, platelet aggregation, fibrinogen and fibrinolytic activity. Ginger did not affect the blood lipids and blood sugar (Bordia, 1997). Ginger on thromboxane synthetase activity was found dose dependent, or only occurs with fresh ginger, and that up to 2 $\mathrm{g}$ of dried ginger is unlikely to cause platelet dysfunction when used 
therapeutically (Lumb, 1994). In a double-blind randomized placebo trial, the effect of the powdered rhizome of ginger Zingiber officinale was tested on seasickness.

Ginger root reduced the tendency of vomiting and cold sweating significantly better than placebo did ( $\mathrm{p}<0.05)$ (Grontved, 1988). The effect of powdered ginger root (Zingiber officinale) upon vertigo and nystagmus following caloric stimulation of the vestibular system was studied in eight healthy volunteers in a double-blind crossover placebo trial (Grontved, 1986.). The effect of ginger root (Zingiber isrhizoma) on gastrointestinal motility was examined based on its ability to enhance charcoal meal transport in mice. The plant and its active constituents have gastrointestinal motility enhancing effect (Yamahara, 1990).

The effects of these substances were similar to or slightly weaker than those of metoclopramide and donperidone. Dietary supplementation ginger in 20 healthy male volunteers for 7 days was found to enhance platelet aggregation to a significant extent (Varma, 1993).

The following pharmacological and safety evaluation studies (Derelanko 2002, Han, 2003) were carried out on the plant decoction of Zingiber officinalis.

\begin{tabular}{|c|c|c|c|c|}
\hline \multirow{2}{*}{$\begin{array}{l}\text { ACTI } \\
\text { VITY }\end{array}$} & \multicolumn{4}{|c|}{ RESULTS } \\
\hline & Strong & Moderate & Mild & Negative \\
\hline Analgesic (hot plate) & & & & $\sqrt{ }$ \\
\hline Anti-diabetic activity & & $\sqrt{1}$ & & \\
\hline Antidepressant (TST) & & & & V \\
\hline Anti-stress activity (swimming test) & $\sqrt{ }$ & & & \\
\hline $\begin{array}{l}\text { Anti-gastric ulcer effect }(\mathrm{NaOH} \text { rat } \\
\text { model) }\end{array}$ & $\sqrt{ }$ & & & \\
\hline Antithrombotic effect & & $\sqrt{ }$ & & \\
\hline Effect on guinea pig tracheal chain & & & & $\sqrt{ }$ \\
\hline Effect on rabbit jejunum & & $\sqrt{ }$ & & \\
\hline Effect on guinea pig ileum & & & & \\
\hline Effect on rat fundus & & $\sqrt{1}$ & & \\
\hline Effect on detrusor muscle & & V & & \\
\hline Effect on right rat atria (HR) $\downarrow$ & & & & \\
\hline Acute toxicity on mice & & & & $\sqrt{ }$ \\
\hline Locomotor activity test & & & & \\
\hline $\begin{array}{l}\text { Motor co-ordination (grip strength \& } \\
\text { motor activity }\end{array}$ & & & & $\sqrt{ }$ \\
\hline Rectal temperature & & & & $\sqrt{ }$ \\
\hline Body weight & & & & $\sqrt{ }$ \\
\hline $\mathrm{Ld} 50=>10 \mathrm{~g} / \mathrm{kg}$ p.o. in mice & & & & \\
\hline Mortality & & & & $\sqrt{ }$ \\
\hline
\end{tabular}

\section{Conclusion:}

The plant decoction showed moderate anti-diabetic activity; the combination of Zingiber + Musa exhibited anti-gastric ulcer effect in rats and moderate contraction effect on acetylcholine treated detrusor muscle. The decoction was evaluated for its safety in mice, following acute toxicity test. Acute administration of the plant decoction did not produce any noticeable toxic effects in the mice at the doses tested. 

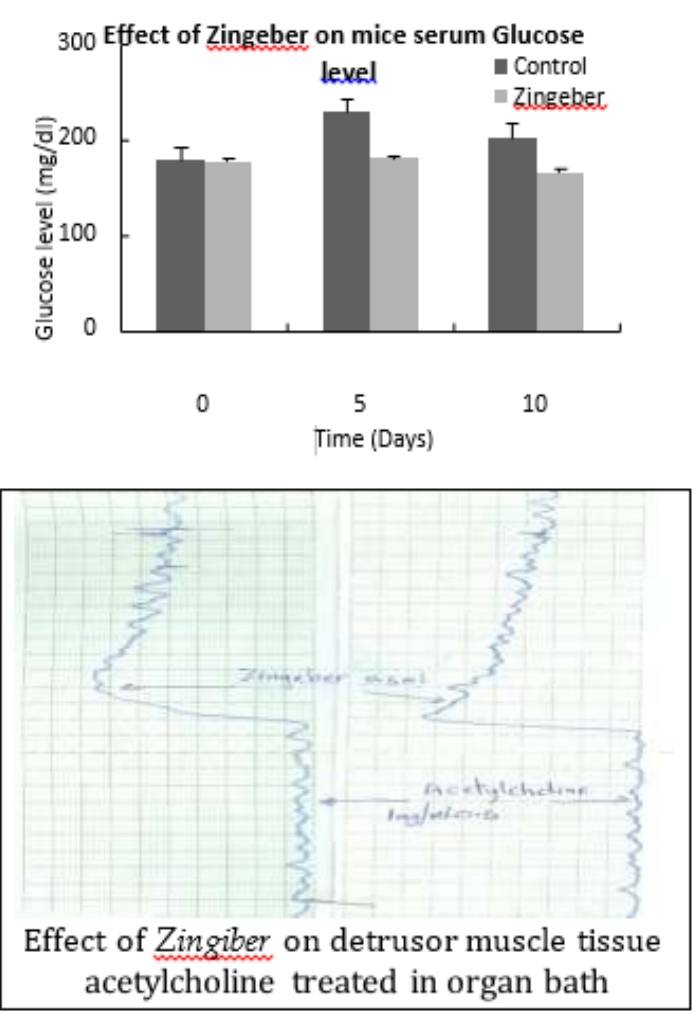

\section{Reference:}

1. Al-Yahya, M. A., Rafatullah, S., Mossa, J. S., Ageel, A. M., Parmar, N. S., \& Tariq, M. (1989). Gastroprotective activity of ginger Zingiber officinale rosc. in albino rats. The American Journal of Chinese Medicine. (17): 51-56.

2. Arfeen, Z., Owen, H., Plummer, J. L., Ilsley, A. H., SorbyAdams, R. A., \& Doecke, C. J. (1995). A double-blind randomized controlled trial of ginger for the prevention of postoperative nausea and vomiting. Anaesth Intensive Care. (23): 449-452.

3. Bauer, A. W., Kirby, W. M., Sherris, J. C., \& Turck, M. (1966). Antibiotic susceptibility testing by a standardized single disk method. Am J Clin Pathol, (45): 493-496.

4. Bhandari, U., Kanojia, R., \& Pillai, K. K. (2005). Effect of ethanolic extract of Zingiber officinale on dyslipidaemia in diabetic rats. Journal of Ethnopharmacology, 97(2): 227-230.

5. Blumenthal, M., Busse, W. R., Goldberg, A., Gruenwald, J., Hall, T., Riggins, C.W., \& Rister, R.S. (1998). Integrative Medicine Communications, Boston, MA: The Complete Commission E Monographs, Therapeutic Guide to Herbal Medicines. 135-136.

6. Bone, M. E., Wilkinson, D. J., Young, J. R., McNeil, J., \& Charlton, S. (1990). Ginger root: A new antiemetic: The effect of ginger root on postoperative nausea and vomiting after major gynaecological surgery. Anaesthesia, (45): 669-671.

7. Bordia, A., Verma, S. K., \& Srivastava, K. C. (1997). Effect of ginger (Zingiber officinale Rosc) and fenugreek (Trigonella foenumgraecum L) on blood lipids, blood sugar, and platelet aggregation in patients with coronary artery disease. Prostaglandins Leukotrienes Essential Fatty Acids. In, Botanical Medicines The Desk Reference for Major Herbal Supplements 2nd ed, (56): 379-384.

8. Bradley, P. R. (Ed). (1992). British Herbal Compendium. (1):
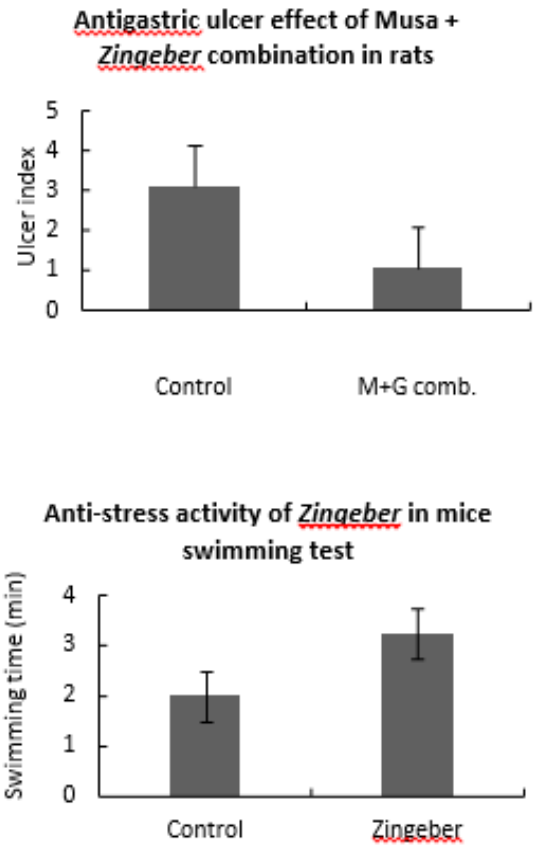

112-114. Bournemouth, Dorset, UK: British Herbal Medicine Association.

9. British Herbal Medicine Association. (1996). British Herbal Pharmacopoeia. 4th ed.: BHMA.

10. Brown, D. J. (1996). Herbal Prescriptions for Better Health. Rocklin, CA: Prima Publishing, 111-118.

11. Careddu, P. (1999). Motion sickness in children: Results of a double-blind study with ginger and dimenhydrinate. Health notes Rev Complementary Integrative Med, 6:102-107.

12. Derelanko, M. J., \& Hollinger, M. A. (2002). Handbook of toxicology. 2nd ed., Boca Raton, USA: CRC Press.

13. Trease, \& Evans. (1996). Pharmacognosy. 14th ed. 105: Saunders, London.

14. Flora of Pakistan. e-floras, Web.

15. Ghazanfar, S. A. (1994). Handbook of Arabian Medicinal Plants. Boca Raton, USA: CRC Press.

16. Grontved, A., Brask, T., Kambskard, J., \& Hentzer, E. (1988). Ginger root against seasickness. A controlled trial on the open sea. ActaOtolaryngol (Stockh), (105): 45-49.

17. Grontved, A. Hentzer, E. (1986). Vertigo-reducing effect of ginger root. A controlled clinical study. ORL J Otorhinolaryngol Relat Spec., (48): 282-286.

18. Han, J., \& Hoosier, G. L. V. J. (2003). Handbook of laboratory science, animal models. 2nd ed. (II). USA: CRC Press.

19. Holtmann, S., Clarke, A. H., Scherer, H., \& Hohn, M. (1989). The anti-motion sickness mechanism of ginger. A comparative study with placebo and dimenhydrinate. Acta- Otolaryngol (Stockh). (108): 168-174.

20. Janssen, P. L., Meyboom, S., Van Staveren, W. A., De Vegt, F., \& Katan, M. B. (1996). Consumption of ginger (Zingiber officinale Roscoe) does not affect ex vivo platelet thromboxane production in humans. Eur J ClinNutr. (50): 772-774.

21. Kapoor, L. D. (2001). Handbook of Ayurvedic medicinal plants. Boca Roton, CRC Press Inc. 341. 
22. Langner, E., Greifenberg, S., \& Gruenwald, J. (1998). Ginger: history and use. Adv Ther. 15(1): 25-44.

23. Lumb, A. B. (1994). Effect of dried Ginger on human platelet function. Thromb Hemostas. . (71): 110-111.

24. Meyer, K., Schwartz, J., Craer, D., \& Keyes, B. (1995). Zingiber officinale (ginger) used to prevent 8-Mop associated nausea. Dermatol Nursing. (7): 242-244.

25. Drugs Control \& Traditional Medicine Division. (2003). Monograph of Unani Medicine. (1): 570. Islamabad, Pakistan: DCTMD.

26. Mothana, R. A. A., Abdo, S. A. A., Hasson, S., Althawab, F. M. N., Alaghbari, S. A. Z. \& Lindequist, U. (2008). Antimicrobial, antioxidant and cytotoxic activities and phytochemical screening of some Yemeni medicinal plants. Evidence-Based Complementary and Alternative Medicine, 7(3): 323-330.

27. Currniff, P. (1999). Official Methods of Analysis of AOAC International. 16th ed.1 (2).

28. Phillips, S., Ruggier, R., \& Hutchinson, S. E. (1993). Zingiber officinale (ginger)-an antiemetic for day case surgery. Anaesthesia, (48): 715-717.

29. World Health Organization. (1998). Quality control methods for medicinal plant materials. Geneva: WHO.

30. Rastogi, R. P., \& Mehrotra, B. N. (1991). Compendium of Indian medicinal plants. (2); 718. New Delhi: PID.

31. Rastogi, R. P., \& Mehrotra, B. N. (1993). Compendium of
Indian medicinal plants. (3); 619. New Delhi: PID.

32. Rastogi, R. P., \& Mehrotra, B. N. (1995). Compendium of Indian medicinal plants. (4); 774. New Delhi: PID.

33. Rastogi, R. P., \& Mehrotra, B. N. (1998). Compendium of Indian medicinal plants. (5), 908. New Delhi: PID.

34. Charles, R., Garg, S. N., \& Kumar, S. (2000). New gingerdione from the rhizomes of Zingiber officinale, Fitoterapia, (71): 716718.

35. Ribenfeld, D., \& Borzone, L. (1999). Randomized double-blind study comparing ginger (Zintona) with dimenhydrinate in motion sickness. Health notes Rev Complementary Integrative Med, (6): 98-101.Suekawa, M., Ishige, A., Yuasa, K., Sudo, K., Aburada, M., \& Hosoya, E. (1984). Pharmacological studies on ginger. I. Pharmacological actions of pungent constituents, (6)gingerol and (6)-shogaol. J Pharmacobiodyn, (7): 836-848.

36. Verma, S. K., Singh, J., Khamesra, R., \& Bordia, A. (1993). Effect of ginger on platelet aggregation in man. Indian J Med Res, (98): 240-242.

37. Wagner, H., \& Bladt, S. (1996). Plant drug analysis-a thin layer chromatography atlas. 2nd ed., Springer-Verlag, Berlin Heidelberg.

38. Geneva: WHO.World Health Organization (1999). Monographs on selected medicinal plants. (1): 280.

39. Yamahara, J., Huang, Q. R, Li, Y. H., Xu, L., \& Fujimura, H. (1990). Gastrointestinal motility enhancing effect of ginger and its active constituents. Chem Pharm Bull, (38): 430-431.

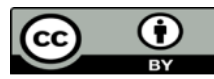

This work is licensed under Creative Commons Attribution 4.0 License

To Submit Your Article Click Here: Submit Manuscript

DOI: $10.31579 / 2640-1045 / 106$
Ready to submit your research? Choose Auctores and benefit from:

$>$ fast, convenient online submission

$>$ rigorous peer review by experienced research in your field

$>$ rapid publication on acceptance

$>$ authors retain copyrights

$>$ unique DOI for all articles

$>$ immediate, unrestricted online access

At Auctores, research is always in progress.

Learn more https://www.auctoresonline.org/journals/journal-of-clinicaland-laboratory-research 